Article

MARCHEZAN, M.G. ${ }^{1}$

AVILA, L.A. ${ }^{1 *}$

SCHAEDLER, C.E. ${ }^{2}$

AMARANTE, L. ${ }^{1}$

SCHERNER, A. ${ }^{1}$

SCHREIBER, F. ${ }^{1}$

\section{Biochemical Alterations of Weeds in Response to Stress Caused by Herbicides and Total Plant SUBMERSION}

\author{
Alterações Bioquímicas de Plantas Daninhas em Resposta ao Estresse Causado \\ por Herbicidas e Submersão Total de Plantas
}

\begin{abstract}
The maximum biological efficiency of a herbicide is performed when the plants are in favorable condition to absorb and metabolize it. Stress situations, such as total submersion, cause stress in plants, reducing weed control efficiency and crop yield. The objective of this study was to verify whether different soil water content and herbicide treatments alter the components of the secondary metabolism and cause cellular damage in weed species Two experiments were conducted (I and II) in a completely randomized experimental design with a factorial scheme $(2 \times 2 \times 4$ and $2 \times 5$, respectively) and three replicates. The first experiment was conducted with two species (Leersia hexandra and Luziola peruviana), which were submitted to four herbicide treatments and soil moisture levels (field capacity and total submersion). Experiment II was performed with cockspur grass plants submitted to five herbicide treatments and the same soil moisture levels from experiment I. Leaf samples were collected for laboratory analyses seven days after establishing the soil moisture levels. Assessmentes were made for the levels of chlorophyll and carotenoids, activity of antioxidant enzymes, as well as levels of hydrogen peroxide and cellular damage. The results showed that all plant species studied showed higher oxidative stress under field capacity than under submersion. $L$. hexandra shows greater oxidative stress than $L$. peruviana regardless of the treatment applied: water regime or herbicide. Furthermore, the associations of glyphosate + clomazone and glyphosate + mixture of imazapyr + imazapic caused greater oxidative stress in L. hexandra and L. peruviana than glyphosate alone. All herbicides caused lipid peroxidation, reduced enzyme activity decreased concentrations of total chlorophyll, chlorophyll $a$ and carotenoids on cockspur grass.
\end{abstract}

Keywords: Luziola peruviana, Leersia hexandra, Echinochloa crus-galli, oxidative stress, chemical control.

RESUMO - Para que um hercida exerça sua máxima eficiência biológica, as plantas devem estar em condições favoráveis para sua absorção e metabolização. Situações de estresse como, por exemplo, submersão total causam estresse em plantas, podendo dificultar o controle de plantas daninhas e, ainda, limitar o potencial produtivo das culturas. O presente trabalho teve por objetivo verificar as alterações em compostos do metabolismo secundário e os danos celulares em plantas daninhas em função de diferentes regimes hídricos e tratamentos herbicidas. Dois experimentos foram conduzidos (I e II), ambos arranjados em delineamento experimental inteiramente casualizado em esquema fatorial $(2 \times 2 \times 4$ e $2 \times 5$, respectivamente), com três repetições. No experimento I, duas espécies de gramaboiadeira (Leersia hexandra e Luziola peruviana) foram testadas quanto aos

1 Universidade Federal de Pelotas (UFPel), Pelotas-RS, Brasil. ${ }^{2}$ Universidade Federal do Pampa (Unipampa), Itaqui-RS, Brasil.

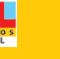


efeitos de quatro tratamentos herbicidas e dois regimes hídricos (capacidade de campo e submersão total). O experimento II foi conduzido com plantas de capim-arroz submetidas a cinco tratamentos herbicidas e aos mesmos regimes hídricos utilizados no experimento I. Amostras de folhas das espécies foram coletadas aos sete dias após a aplicação dos regimes hídricos, para posterior análise em laboratório. Nestas foram avaliados os teores de clorofila e carotenoides, atividades de enzimas do sistema antioxidativo, níveis de peróxido de hidrogênio e danos celulares. Os resultados obtidos demonstram que todas as espécies estudadas apresentam maior estresse oxidativo em capacidade de campo do que quando submersas. L. hexandra apresenta maior estresse oxidativo do que $\boldsymbol{L}$. peruviana, independentemente do tratamento: regime hídrico ou herbicida. As associações de glyphosate + clomazone e glyphosate + imazapyr + imazapic causaram maior estresse oxidativo em ambas as espécies do que o uso isolado de glyphosate. Todos os herbicidas promoveram, no capim-arroz, peroxidação lipídica, redução da atividade enzimática e redução das concentrações de clorofila total, clorofila a $e$ carotenoides.

Palavras-chave: Luziola peruviana, Leersia hexandra, Echinochloa crus-galli, estresse oxidativo, controle químico.

\section{INTRODUCTION}

The presence of weeds is one of the main factors limiting crop productivity. In paddy rice these species are directly associated with yield losses (Galon and Agostinetto, 2009) and are the source of indirect economical losses due to increase in production costs and depreciation of cultivated areas and the product harvested (Menezes and Silva, 1998). Weed management is accomplished through physical, chemical, biological and mechanical methods (Zimdahl, 1980). However, the chemical strategy, which relies on herbicide applications, is the most used one.

The performance of a herbicide is a function of several factors, however, it is known that to express its maximum biological efficiency the compound must be applied when plants present favorable conditions to absorb and metabolize it (Devine et al., 1983). Therefore, environmental conditions that induce stress in plants, can hamper weed control and limit crop yield potential, because both absorption and translocation are reduced in stressed plants (Hess, 1995).

In Rio Grande do Sul (RS), rice cultivation areas, especially those near rivers, are subject to submersion in rainy periods. Thus, both crop and weed control can be affected due to submersion. Some studies have shown that high levels of soil moisture can affect herbicide efficiency, as for glyphosate, which shows low efficiency against grasses in flooded areas (Noldin et al., 2002; Scherner et al., 2017).

The most troublesome weed species in rice cultivation in RS are the ones that have the capacity to adapt and survive in flooded conditions. Thus, species such as Echinochloa crus-galli (cockspur grass), Leersia hexandra (rice cutgrass) and Luziola peruviana (peruvian watergrass) stand out. They occur at high levels of infestation and are distributed in practically all rice fields in Southren Brazil (Noldin et al., 2002).

Cockspur grass plants have high competitive ability compared to rice (Galon et al., 2007; Agostinetto et al., 2007). Even after applying control measures that suppress up to $99 \%$ of the infestation, losses on rice productivity can be observed (Agostinetto et al., 2007; Pinto et al., 2008). The control of this species is mainly achieved by herbicides that inhibit the acetolactate synthase (ALS) enzyme. These herbicides are widely used in RS, mainly due to low doses applied, broad spectrum of action, low toxicity for man and animals and high translocation capacity in plants (Leite et al., 1998; Vidal, 2002). Another important group of herbicides used to control cockspur grass are the ones that inhibit the ACCase enzyme, because they are highly selectivity for rice and have broad spectrum of action against grass weeds (Vidal, 2002).

Several challenges have being faced to control rice cutgrass and peruvian watergrass in rice fields, especially in agricultural areas with poor drainage in the fallow season and where soil preparation is predominantly performed under flooded conditions (Noldin et al., 2002). Moreover, the absence of herbicides registered to control these species post-emergence in rice has contributed to their proliferation and consequently has increased productivity losses 
(Scherner et al., 2014). Currently glyphosate has been used to burndown these species in the fallow season, but it has low efficiency when applied under high soil moisture and low temperatures (Noldin et al., 2002; Scherner et al., 2017), which are quite frequent in RS during this season.

The efficiency of chemical control against weeds is usually assessed by observing plant growth parameters, which include height, foliar area, tillering, reduction of shoot biomass and visual analysis of herbicide toxicity. However, few studies evaluate physiological changes in plant tissues in response to stress caused by the application of herbicides such as changes in biochemical parameters in tissues, which may indicate oxidative stress.

Oxidative stress is characterized by an increase on the production of reactive oxygen species (ROS), due to alterations on the antioxidant system or unbalance among them (Barbosa et al., 2014). The degree of oxidative stress in a cell is determined by the amount of superoxide radicals, hydrogen peroxide and hydroxyl radicals (Barreiros et al., 2006). To reduce the damage caused by oxidative stress, plants have defense systems that can be enzymatic or not, which allow the elimination of ROS and protect them from oxidative damage. Thus, weeds may present metabolic alterations in response to total submersion, which may interfere on the efficiency of herbicide control. Therefore, a more detailed study on changes in biochemical parameters as a function of herbicide applications in plants under water stress is of critical importance. In view of the above, the objective of this study was to verify whether different soil water content and herbicide treatments alter the components of the secondary metabolism and cause cellular damage in weed species.

\section{MATERIALS AND METHODS}

Two experiments (I and II) were conducted in a greenhouse during in 2013. The experimental units consisted of plastic pots with $1.5 \mathrm{~L}$ capacity, which were filled with $800 \mathrm{~g}$ of soil sieved and without clods. The soil used in the experiment was an Albaquaf soil that had no herbicide application history in the last five years and was collected from the A horizon of an area cultivated with rice. The soil had the following characteristics: water $\mathrm{pH}(1: 1)=5.1$; CEC (cation-exchange capacity) $\mathrm{pH} 7=5.4 \mathrm{cmol}_{\mathrm{c}} \mathrm{dm}^{-3}$; organic matter $=1.2 \%$; clay $=15 \%$; texture $=4 ; \mathrm{Ca}=1.8 \mathrm{cmol}_{\mathrm{c}} \mathrm{dm}^{-3}$; $\mathrm{Mg}=1 \mathrm{cmol}_{\mathrm{c}} \mathrm{dm}^{-3} ; \mathrm{Al}$ exchangeable $=0.2 \mathrm{cmol}_{\mathrm{c}} \mathrm{dm}^{-3} ; \mathrm{P}$ available $=4.3 \mathrm{mg} \mathrm{dm}^{-3} ;$ and $\mathrm{K}$ exchangeable $=30 \mathrm{mg} \mathrm{dm}^{3}$. After filled with soil the pots were placed in plastic boxes with $73 \mathrm{~L}$ capacity.

\section{Experiment I}

Rice cutgrass and peruvian watergrass plants ( $L$. hexandra and $L$. peruviana, respectively) were collected from a rice field and stolons from these plants were sectioned and transplanted in each experimental unit (10 stolons with three buds per unit), therefore, originating at least 10 plants per pot. After transplant, the soil was kept close to field capacity until the treatments were applied.

The experimental design used was a completely randomized, in a factorial scheme $(2 \times 2 \times 4)$ with three replications. Factor A consisted of two species, rice cutgrass and peruvian watergrass. Factor B consisted of four herbicidal treatments: glyphosate $\left(2.160 \mathrm{~g}\right.$ a.e. $\left.\mathrm{ha}^{-1}\right)+$ imazapyr + imazapic $\left(36.75+12.25 \mathrm{~g}\right.$ a.i. ha $\left.{ }^{-1}\right)+0.5 \%$ v.v. of adjuvant (aromatic hydrocarbon chemical group, methyl esters and phosphate polyol); glyphosate ( 2.160 g a.e. ha $\left.{ }^{-1}\right)$; glyphosate $\left(2.160 \mathrm{~g}^{2}\right.$ a.e. ha-1) + clomazone (500 g a.i. ha $\left.{ }^{-1}\right)+0.5 \%$ v.v. (paraffinic mineral oil). Moreover, a control treatment without herbicide application was also included. Herbicides application took place 90 days after transplanting the stolons. The spraying was performed with a precision knapsack sprayer, pressurized by $\mathrm{CO}_{2}$, equipped with a spray boom with four nozzle tips of a fan-type flat jet, series 110-02, spaced of $50 \mathrm{~cm}$, calibrated to apply a volume of spray solution of $150 \mathrm{~L} \mathrm{ha}^{-1}$. Factor C consisted of two soil moisture levels, field capacity and total submersion, established 24 hours after herbicide application. Soil in field capacity was kept at $15 \mathrm{kPa}$ through the use of moisture sensors (Watermark ${ }^{\mathrm{TM}}$ ). For the submersion treatments, plastic boxes were filled with water to the maximum level, establishing a water layer of $20 \mathrm{~cm}$ depth above the soil level.

Plant material was collected seven days after application (DAT) of soil moisture levels from the 10 plants per experimental unit (three leaves per plant collected along the stolon) These 
samples were frozen in liquid nitrogen and immediately stored at $-80{ }^{\circ} \mathrm{C}$ for further determination of hydrogen peroxide content, lipidic peroxidation, antioxidant enzymes activity, chlorophylls, carotenoids and phenolic compounds.

\section{Experiment II}

For the second experiment, cockspur grass seeds (Echinochloa crus-galli) were collected in an area cultivated with rice and sown in early spring in 2013 , originating 10 plants per pot. A completely randomized experimental design was used in a factorial scheme $(2 \times 5)$ with three replicates. Factor A consisted of the same soil moisture levels used in the first experiment and factor B consisted of five herbicide treatments: penoxsulam (50 g a.i. ha $\left.{ }^{-1}\right)$; bispyribac-sodium (60 g a.i. ha-1); imazapyr + imazapic (73.5 + 24.5 g a.i. ha-1); cyhalofop-butyl (315 g a.i. ha $\left.{ }^{1}\right)$; and a control treatment without herbicide application. After planting, the soil in the experimental units was kept at field capacity $(15 \mathrm{kPa})$ until application of the treatments. Herbicide treatments were applied when the cockspur grass plants were found with three leaves completely expanded, with the same equipment used in the first experiment.

Soil moisture levels were established 24 hours after herbicide application and plant material was collected seven DAT from 10 plants per experimental unit (three leaves per plant collected along the stolon). The same paremeters evaluated on Experiment I were evaluated in the samples from this study.

\section{Determination of the content of hydrogen peroxide $\left(\mathrm{H}_{2} \mathrm{O}_{2}\right)$ and peroxidation of lipids}

Cellular tissue damage was determined by hydrogen peroxide content $\left(\mathrm{H}_{2} \mathrm{O}_{2}\right)$, as described by Loreto and Velikova (2001) and thiobarbituric acid reactive species (TBARS) via accumulation of malondialdehyde (MDA), as described by Heath and Packer (1968). To carry out these analyses, $0.2 \mathrm{~g}$ of leaves were macerated with liquid nitrogen, homogenized in $2 \mathrm{~mL}$ of trichloroacetic acid (TCA) $0.1 \%(\mathrm{~m} / \mathrm{v})$ and centrifuged at $14,000 \mathrm{rpm}$ for 20 minutes. To quantify $\mathrm{H}_{2} \mathrm{O}_{2}$, aliquots of $0.2 \mathrm{~mL}$ of the supernatant were added in $0.8 \mathrm{~mL}$ of phosphate buffer $10 \mathrm{mM}(\mathrm{pH} 7.0)$ and $1 \mathrm{~mL}$ of potassium iodide $1 \mathrm{M}$. The solution was allowed to stand for 10 minutes at room temperature and the absorbance was read at $390 \mathrm{~nm}$. The concentration of $\mathrm{H}_{2} \mathrm{O}_{2}$ was determined by standard curve and expressed in $\mathrm{mM} \mathrm{g}^{-1}$.

To determine TBARS, aliquots of $0.5 \mathrm{~mL}$ of the supernatant, as described previously, were added to $1.5 \mathrm{~mL}$ of thiobarbituric acid (TBA) $0.5 \%(\mathrm{~m} / \mathrm{v})$ and trichloroacetic acid $10 \%(\mathrm{~m} / \mathrm{v})$ and incubated at $90{ }^{\circ} \mathrm{C}$ for 20 minutes. Then the reaction was stopped on an ice bath for 10 minutes. The absorbance was read at $532 \mathrm{~nm}$, discounting the unspecific absorbance at $600 \mathrm{~nm}$. The MDA concentration was calculated using the absorptivity coefficient of $155 \mathrm{mM} \mathrm{cm}^{-1}$ and the results were expressed in $\mathrm{nM} \mathrm{MDA} \mathrm{g}^{-1}$ of $\mathrm{FM}$.

\section{Foliar photosynthetic pigments}

Chlorophyll content ( $a, b$ and total) and carotenoids were determined from a sample of $0.1 \mathrm{~g}$ of shoots macerated in a crucible in the presence of $5 \mathrm{~mL}$ of acetone at $80 \%(\mathrm{v} / \mathrm{v})$. The material was centrifuged at $12,000 \mathrm{rpm}$ for 10 minutes and the supernatant was transferred to a $25 \mathrm{~mL}$ volumetric flask, adding acetone at $80 \%(\mathrm{v} / \mathrm{v})$ to this volume. The total carotenoid and $a, b$ and total chlorophyll contents were calculated according to a formula proposed by Lichtenthaler (1987) from absorbance of the solution obtained by spectrophotometry at 647,663 and $470 \mathrm{~nm}$ and the results were expressed in $\mathrm{mg} \mathrm{g}^{-1}$ of $\mathrm{FM}$.

\section{Preparation of enzymatic extract}

To determine the enzymatic activity, $0.2 \mathrm{~g}$ of shoot sample were macerated with the aid of liquid nitrogen and $0.02 \mathrm{~g}$ of polyvinylpyrrolidone (PVPP). Then, $900 \mu \mathrm{L}$ of phosphate buffer $200 \mathrm{mM}$ (pH 7.8), $18 \mu \mathrm{L}$ of EDTA (ethylenediaminetetraacetic acid) $10 \mathrm{mM}, 180 \mu \mathrm{L}$ of ascorbic acid $200 \mathrm{mM}$ and $702 \mu \mathrm{L}$ of ultrapure water and centrifuged at $14,000 \mathrm{rpm}$ were added at $4{ }^{\circ} \mathrm{C}$ for 20 minutes. 
The supernatant was collected and used for further analysis. From this extract the protein content was quantified by Bradford's (1976) method and the standard curve was drawn with globulin, the results being expressed in $\mathrm{mg} \mathrm{g}^{-1} \mathrm{FM}$.

\section{Determination of activities of antioxidant enzymes}

Catalase activity (CAT; EC 1.11.1.6) was determined by the consumption of $\mathrm{H}_{2} \mathrm{O}_{2}$ (coefficient of extinction of $39.4 \mathrm{mM} \mathrm{cm}^{-1}$ ) by the method by Azevedo et al. (1998). For this, the reaction of $1 \mathrm{~mL}$ of potassium phosphate buffer $200 \mathrm{mM}$ (pH 7.0), $850 \mu \mathrm{L}$ of ultrapure water, $100 \mu \mathrm{L}$ of hydrogen peroxide $250 \mathrm{mM}$ and $50 \mu \mathrm{L}$ of the extract. Absorbance readings at the wavelength of $240 \mathrm{~nm}$ were carried out in a spectrophotometer (Ultrospec 6300 Pro UV/Visible - Amersham Bioscience) for $90 \mathrm{sec}$ at $7 \mathrm{sec}$ intervals.

Ascorbate peroxidase (APX; EC 1.11.1.11) activity was determined according to Azevedo et al. (1998) with modifications by means of the consumption of $\mathrm{H}_{2} \mathrm{O}_{2}$ (extinction coefficient of $\left.2.9 \mathrm{mM} \mathrm{cm}^{-1}\right) .1 \mathrm{~mL}$ of potassium phosphate buffer $200 \mathrm{mM}(\mathrm{pH} 7.0), 750 \mu \mathrm{L}$ of ultrapure water, $100 \mu \mathrm{L}$ of ascorbic acid $10 \mathrm{mM}, 100 \mu \mathrm{L}$ of hydrogen peroxide $2 \mathrm{mM}$ and $50 \mu \mathrm{L}$ of extract were used. Absorbance readings at the wavelength of $290 \mathrm{~nm}$ were carried out in a spectrophotometer (Ultrospec 6300 Pro UV/Visible - Amersham Bioscience) for 90 seconds at 7 second intervals. For calculation purposes for both CAT and APX activities it was considered that the decrease of one unit of absorbance was equivalent to one active unit (AU). The total extract activities were determined from the amount of extract that reduced the absorbance reading in an AU and expressed in $\mathrm{AU} \mathrm{mg}^{-1}$ protein minute ${ }^{-1}$.

Superoxide dismutase (SOD; EC 1.15.1.1) activity was determined according to a methodology adapted from Peixoto (1999) by calculating the amount of extract that inhibited $50 \%$ of the NBT (nitro blue tetrazolium) reaction and expressed in $\mathrm{AU} \mathrm{m \textrm {m } ^ { - 1 }}$ protein minute ${ }^{-1} .1 \mathrm{~mL}$ of potassium phosphate buffer $100 \mathrm{mM}$ (pH 7.8), $400 \mu \mathrm{L}$ of methionine $70 \mathrm{mM}, 20 \mu \mathrm{L}$ of EDTA $10 \mu \mathrm{M}, 390 \mu \mathrm{L}$ of ultrapure water, $150 \mu \mathrm{L}$ of NBT $1 \mathrm{mM}, 20 \mu \mathrm{L}$ of riboflavin $0.2 \mathrm{mM}$ and $20 \mu \mathrm{L}$ of extract incubated for 10 minutes in a 15 watt fluorescent lamp and the absorbance reading was performed in a spectrophotometer (Ultrospec 6300 Pro UV/Visible - Amersham Bioscience) in the wavelength of $560 \mathrm{~nm}$. For the purpose of calculation, blank reaction was considered as being tubes that did not contain extracts, exposed and not exposed to light. The activity was determined by calculating the amount of extract that inhibited $50 \%$ of the NBT and expressed in AU mg protein minute $^{-1}$.

Data were analyzed for normality by the Shapiro-Wilk test and homoscedasticity by the Hartley's test. Thereafter, data was submitted to analysis of variance $(p \leq 0.05)$ by the t test to compare the means in case of a significant difference among species and water regimes or Duncan's test $(\mathrm{p} \leq 0.05)$ for comparison among the herbicide treatments.

\section{RESULTS AND DISCUSSION}

\section{Experiment I}

There was no interaction between soil moisture regimes, herbicides and species in relation to the contents of $\mathrm{H}_{2} \mathrm{O}_{2}$ and TBARS. Therefore, the average test was performed considering the simple effect of each treatment (soil moisture and herbicide treatments). In general, L. peruviana presented lower content of $\mathrm{H}_{2} \mathrm{O}_{2}$ than L. hexandra: 1.93 and $2.25 \mathrm{mM} \mathrm{g}^{-1}$ of FM, respectively. However, the content of TBARS did not vary between species, being of 26.5 and $25.9 \mathrm{nmol} \mathrm{g}^{-1}$ of FM for L. peruviana and L. hexandra, respectively (Table 1 ).

Plants submitted to the herbicide treatments comprising the mixture of glyphosate + formulated mixture of imazapyr + imazapic and glyphosate + clomazone presented higher contents of $\mathrm{H}_{2} \mathrm{O}_{2}$ and TBARS than the single application of glyphosate (Table 1). Thus, the use of glyphosate associated with other herbicides caused higher rates of oxidative stress, which might result in higher control efficiency.

Although the glyphosate's mode of action is not exerted through mechanisms that generate free radicals, they may result from the large proliferation of free amino acids that can act as 
Table 1 - Hydrogen peroxide $\left(\mathrm{H}_{2} \mathrm{O}_{2}\right)$ levels of thiobarbituric acid (TBARS) reactive species in leaves of southern cut-grass and water grass in response to water regimes and application of herbicides

\begin{tabular}{|l|c|c|}
\hline \multicolumn{1}{|c|}{ Treatment } & $\begin{array}{c}\mathrm{H}_{2} \mathrm{O}_{2} \\
\left(\mathrm{mM} \mathrm{g}^{-1} \text { of FM) }\right.\end{array}$ & $\begin{array}{c}\text { TBARS } \\
\text { (nmol MDA g }\end{array}$ \\
\hline & \multicolumn{2}{|c|}{ Her FM) } \\
\hline Control & $1.34 \mathrm{c}^{(1)}$ & $19.09 \mathrm{c}^{(1)}$ \\
\hline Glyphosate + imazapyr + imazapic & $2.63 \mathrm{a}$ & $32.59 \mathrm{a}$ \\
\hline Glyphosate & $1.96 \mathrm{~b}$ & $24.09 \mathrm{bc}$ \\
\hline Glyphosate + clomazone & $2.60 \mathrm{a}$ & $28.47 \mathrm{ba}$ \\
\hline & & \multicolumn{1}{|c|}{ Water regime } \\
\hline Field capacity & $2.30 \mathrm{~A}^{(2)}$ & $26.08 \mathrm{~A}$ \\
\hline Submersion & $1.87 \mathrm{~B}$ & $24.80 \mathrm{~A}$ \\
\hline
\end{tabular}

${ }^{(1)}$ Lower case letters compare herbicides by the Duncan's test $(\mathrm{p} \leq 0.05)$ and ${ }^{(2)}$ upper case letters compare water or species by the $t$ test $(\mathrm{p} \leq 0.05)$, both in the columns.

antioxidants (Moldes, 2006). In a study carried out with maize leaves, the application of glyphosate increased lipidic peroxidation and ion flow, suggesting that glyphosate is responsible some how for the production of ROS (Sergiev et al., 2006).

$\mathrm{H}_{2} \mathrm{O}_{2}$ content in $L$. peruviana and $L$. hexandra was higher when plants were under field capacity than when submerged, indicating that plants under field capacity were under oxidative stress, which may affect cellular functions, damage nucleic acids and oxidize proteins and lipids (Gill and Tuteja, 2010). Generally when plants are under stress, herbicide efficiency is reduced (Hess, 1995). However, it was verified that in flooded soil the susceptibility of $L$. peruviana and $L$. hexandra to glyphosate was lower, especially for $L$. peruviana, which under these conditions presents greater tolerance to the herbicide than L. hexandra (Scherner et al., 2017). The low efficiency of the herbicide in this study was mainly associated to the fact that these species develop better when soil moisture content is higher, which corroborates with the results of $\mathrm{H}_{2} \mathrm{O}_{2}$ levels found in this study.

As for the results obtained in the evaluation of the SOD enzyme activity, there was an interaction between the species and soil moisture regimes (Table 2). L. peruviana showed higher SOD activity than $L$. hexandra in the field capacity regime but this enzyme activity did not differ when the species were submitted to submersion. Comparing the water regimes, SOD enzyme activity was lower only in $L$. peruviana plants when submerged.

The lower SOD content observed for L. peruviana when in submersion corroborates with $\mathrm{H}_{2} \mathrm{O}_{2}$ results, confirming that in field capacity the plants were more stressed. Similar results have been found by Marchezan et al. (2017), where the rice cultivar BRS Querência presented an increased activity of SOD enzyme, which may be associated to the increase in $\mathrm{H}_{2} \mathrm{O}_{2}$ levels, demonstrating that SOD activity probably stimulated the production of reactive oxygen species (ROS). To reduce the damage caused by oxidative stress, plants have a defense system that includes several antioxidant enzymes in different cell compartments. Among the main enzymes are superoxide dismutase (SOD) which, together with other enzymes, such as catalase (CAT) and ascorbate peroxidase (APX), promote the elimination of ROS, the main cause of oxidative stress (Barbosa et al., 2014). The balance of

Table 2 - SOD enzyme activity, carotenoids concentration and total chlorophyll in leaves of herbicides submitted to the application of herbicides in response to water regimes

\begin{tabular}{|c|c|c|}
\hline Water regimes & Leersia hexandra & Luziola peruviana \\
\hline & \multicolumn{2}{|c|}{$\mathrm{SOD}\left(\mathrm{AU} \mathrm{mg}{ }^{-1}\right.$ prot. $\left.\mathrm{min}^{-1}\right)$} \\
\hline Field capacity & $30.55 \mathrm{~B}^{(1)} \mathrm{a}^{(2)}$ & $46.97 \mathrm{Aa}$ \\
\hline Submersion & $39.29 \mathrm{Aa}$ & $35.11 \mathrm{Ab}$ \\
\hline \multirow[t]{2}{*}{ Averages } & 34.7 & 41.4 \\
\hline & \multicolumn{2}{|c|}{ Concentration of carotenoids (mg. $\left.\mathrm{g}^{-1} \mathrm{FM}\right)$} \\
\hline Field capacity & $0.49 \mathrm{Ba}$ & $0.92 \mathrm{Aa}$ \\
\hline \multirow[t]{2}{*}{ Submersion } & $0.54 \mathrm{Aa}$ & $0.69 \mathrm{Ab}$ \\
\hline & \multicolumn{2}{|c|}{ Concentration of total chlorophyll $\left(\mathrm{mg} \cdot \mathrm{g}^{-1} \mathrm{FM}\right)$} \\
\hline Field capacity & $0.56 \mathrm{Bb}$ & $1.16 \mathrm{Aa}$ \\
\hline Submersion & $0.78 \mathrm{Aa}$ & $1.03 \mathrm{Aa}$ \\
\hline Averages & 0.67 & 1.09 \\
\hline
\end{tabular}

(1) Upper case letters compare the species of southern cut-grass and water grass in the row while ${ }^{(2)}$ lower case letters compare the water regimes in the column, both by the $t$ test $(p \leq 0.05)$. suppressing toxic levels of ROS in cells (Barbosa et al., 2014). The involvement and role of antioxidants as plants protection agents against oxidative stress has been demonstrated in 
several studies involving abiotic stress. For example, Wang et al. (2007) have found an increase in SOD production in response to oxidative stress induced by anoxia.

There was no interaction between the factors studied for the CAT enzyme activity. However, CAT was higher in $L$. hexandra than in $L$. peruviana plants subjected to field capacity than with the total submersion regime, being 0.49 and $0.28 \mathrm{AU} \mathrm{mg}^{-1}$ prot. $\mathrm{min}^{-1}$, respectively (data not shown). This result may be related as well to the increased content of $\mathrm{H}_{2} \mathrm{O}_{2}$ in plants in field capacity condition. Furthermore, differences among herbicide treatments were observed, with CAT activity values being lower for all herbicides compared to the control. CAT values in control plants were $0.57 \mathrm{AU} \mathrm{mg}^{-1}$ prot. $\mathrm{min}^{-1}$, while for herbicides treatments were $0.28,0.39$ and $0.36 \mathrm{AU} \mathrm{mg}^{-1}$ prot. $\mathrm{min}^{-1}$ for glyphosate + formulation mixture of imazapyr + imazapic, glyphosate and glyphosate + clomazone, respectively.

Similar results were observed by Abu-Irmaileh and Jordan (1978), in which the decrease of CAT content in leaves of Cyperus rotundus treated with glyphosate was attributed to the inhibition of ä-aminolevulinic (AAL). Glyphosate inhibits chlorophyll synthesis due to the inhibition of AAL synthesis (Cole, 1985). In plants, AAL synthesizes porphyrins, which are incorporated into important proteins, such as cytochromes, CAT and POX (partial oxidation) (Moldes, 2006). Therefore, the CAT enzyme activity reduction is directly related to the use of the herbicide.

In the present study, no change was observed for the APX enzyme (data not shown). Herbicide treatments did not alter carotenoid concentrations, even for clomazone, which inhibits carotenoid synthesis. This result is possibly explained by the development stage that plants received the herbicide (stolons between 20 and $30 \mathrm{~cm}$ ) because the main form of absorption of clomazone is radicular. Therefore, when applied in preemergence, this herbicide has higher efficiency (Sanchotene et al., 2010).

However, there was a significant interaction among the species and the soil moisture regimes regarding carotenoids concentration (Table 2). L. hexandra presented a lower concentration of carotenoids than $L$. peruviana when in field capacity while there were no differences among species when they were submerged. Among water regimes, higher levels of carotenoids were observed for $L$. peruviana in field capacity than under submersion but, for $L$. hexandra, there were no differences among water regimes.

Regarding the concentration of total chlorophyll, no differences were observed among herbicide treatments. Probably the seven-day interval between application and evaluation was not enough to provide a significant reduction in total chlorophyll content since the death of sensitive plants only occurs within 20 days after application (Vargas, 2003). However, a significant interaction was observed between species and the soil moisture regimes for this variable.

L. peruviana presented higher concentration of total chlorophyll, differing from $L$. hexandra in the field capacity regime (Table 2). However, there were no differences between the species when submerged. Comparing soil moisture regimes, L. hexandra presented reduction in chlorophyll concentration in the field capacity but no differences were observed between water regimes for L. peruviana.

Weed control by herbicides often depends on morphological and physiological differences among species. However, the differences between the species may be related to the complex antioxidant system consisting of both non-enzymatic and enzymatic components to avoid harmful effects of ROS. It is thus evidenced that a deeper understanding of weed species, taking into account their physiological, biochemical responses, their reproductive forms and life cycle, is necessary to develop a good integrated management program (Silva and Silva, 1997).

\section{Experiment II}

Significant interaction was observed for soil moisture regimes and herbicide treatments for $\mathrm{H}_{2} \mathrm{O}_{2}$ content in E. crus-galli plants. Comparing with the control, a higher level of $\mathrm{H}_{2} \mathrm{O}_{2}$ in plants was observed in herbicide treatments in field capacity (Table 3). On the other hand, when plants were submerged, the $\mathrm{H}_{2} \mathrm{O}_{2}$ content increased only in plants treated with penoxsulam. 
Table 3 - Levels of hydrogen peroxide $\left(\mathrm{H}_{2} \mathrm{O}_{2}\right)$ e APX enzyme activity in leaves of cockspur grass (Echinochloa crus-galli) in response to water regimes and herbicide application

\begin{tabular}{|l|c|c|}
\hline \multicolumn{1}{|c|}{ Treatment } & Field capacity & Submersion \\
\hline & Content of $\mathrm{H}_{2} \mathrm{O}_{2}\left(\mathrm{mM} \mathrm{g}^{-1}\right.$ of $\left.\mathrm{FM}\right)$ \\
\hline Control & $1.05 \mathrm{~A}^{(1)} \mathrm{b}^{(2)}$ & $0.72 \mathrm{Ab}$ \\
\hline Penoxsulam & $1.85 \mathrm{Aa}$ & $1.51 \mathrm{Aa}$ \\
\hline Bispyribac-sodium & $1.98 \mathrm{Aa}$ & $0.75 \mathrm{Bb}$ \\
\hline Imazapyr + imazapic & $2.16 \mathrm{Aa}$ & $0.95 \mathrm{Bb}$ \\
\hline Cyhalofop-butyl & $1.91 \mathrm{Aa}$ & $0.82 \mathrm{Bb}$ \\
\hline & $\mathrm{APX}\left(\mathrm{AU} \mathrm{\textrm {mg } ^ { - 1 }}\right.$ prot. $\left.\mathrm{min}^{-1}\right)$ \\
\hline Control & $15.4 \mathrm{Aa}$ & $13.2 \mathrm{Aa}$ \\
\hline Penoxsulam & $13.4 \mathrm{ABa}$ & $8.2 \mathrm{Aa}$ \\
\hline Bispyribac-sodium & $12.1 \mathrm{ABa}$ & $9.1 \mathrm{Aa}$ \\
\hline Imazapyr + imazapic & $9.30 \mathrm{BCa}$ & $11.8 \mathrm{Aa}$ \\
\hline Cyhalofop-butyl & $5.50 \mathrm{Ca}$ & $9.4 \mathrm{Aa}$ \\
\hline
\end{tabular}

(1) Upper case letters compare the herbicide treatments in the row by the Duncan's test $(\mathrm{p} \leq 0.05)$ while ${ }^{(2)}$ lower case letters compare the water regimes in the column by the $t$ test $(\mathrm{p} \leq 0.05)$.
Comparing soil moisture regimes significant differences were only observed between control and penoxsulam treatments. Penoxsulam induced to higher levels of $\mathrm{H}_{2} \mathrm{O}_{2}$ in both soil moisture regimes than control treatments. For the other herbicides, plants in field capacity presented higher $\mathrm{H}_{2} \mathrm{O}_{2}$, indicating that, when submerged, their activity may be slow down or they have reduced efficacy against E. crus-galli.

It was possible to observe that herbicides penoxsulam, cyhalofop-butyl, bispyribacsodium and the formulation mixture of imazapyr + imazapic showed a significant increase in TBARS content, regardless of the soil moisture regime. Thus indicating that cockspur grass plants exhibit oxidative stress when exposed to herbicides, since the control, without herbicide, differed from all the results. These results corroborate with the ones reported by Zabalza et al. (2007), who verified higher levels of TBARS from seven days after application of imazethapyr in treated plants and these differences were even more evident at 10 days after application.

For the activity of the APX enzyme there was an interaction between soil moisture regimes and herbicide treatments (Table 3). When plants were in field capacity, some reduction in enzymatic activity was observed for the cyhalofop-butyl herbicides and for the formulation mixture of imazapyr + imazapic, which differed from the control, whereas there was no reduction of enzymatic activity in the plants submerged for herbicide treatments regarding the control. Although statistical differences were not observed between soil moisture regimes, in general it is possible to observe a slight increase in the activity of the APX enzyme when in field capacity, reinforcing the idea that the plant was more stressed.

In the present study, for the SOD enzyme activity (Table 4), differences were observed between the soil moisture regimes, where, under field capacity, cockspur grass plants presented higher activity than when under total submersion, being 70.64 and $48.45 \mathrm{AU} \mathrm{mg}{ }^{1}$ protein $\mathrm{min}^{-1}$, respectively. Although there was no significant interaction between herbicides and soil moisture regimes for SOD, the higher SOD activity in plants under field capacity may be associated with herbicides under these conditions, resulting in more stressed plants. On the other hand, the herbicides can also cause reduction in enzymatic and non-enzymatic activities as the anoxic treatment is prolonged (Blokhina et al., 2003). Unfolding of the herbicide treatment showed that plants that received cyhalofop-butyl, bispyribac-sodium and the formulated mixture of imazapyr + imazapic showed the greatest reductions in SOD activity, differing from control and treatment with penoxsulam herbicide. These results differ from those observed by Zabalza et al. (2007), where no differences in SOD activity were observed in pea leaves by the application of imazethapyr.

Regarding the CAT enzyme, no interaction between the variables studied was observed but there was a difference between the soil moisture regimes. Similar behavior, as for SOD, was observed in relation to the difference between soil moisture regimes (data not shown), where plants under total submersion showed reduction of CAT activity in relation to field capacity regime, being 0.18 and $0.24 \mathrm{AU} \mathrm{mg}^{-1}$ prot $\mathrm{min}^{-1}$, respectively. Therefore, it can be inferred that the behavior of this enzyme is directly linked to the behavior of the SOD enzyme.

There was a difference between herbicide treatments for the variables total chlorophyll, chlorophyll $a$ and carotenoids (Table 4). For the content of total chlorophyll and carotenoids, the highest content reduction was observed in the penoxsulam and cyhalofop-butyl herbicides, differing from the control. As for the concentration of chlorophyll $a$, all herbicide treatments reduced concentration in relation to the control. 
Table 4 - Content of thiobarbituric acid (TBARS) reactive species, SOD enzyme activity, total chlorophyll concentration, chlorophyll $a$ and carotenoids in leaves of cockspur grass (Echinochloa crus-galli) in response to herbicide application

\begin{tabular}{|c|c|c|c|}
\hline Herbicide treatment & TBARS (nmol MDA & & SOD (AU mg ${ }^{-1}$ prot. $\left.\min ^{-1}\right)$ \\
\hline Control & \multicolumn{2}{|l|}{$13.2 \mathrm{c}^{(1)}$} & $76.65 \mathrm{a}$ \\
\hline Penoxsulam & \multicolumn{2}{|l|}{$22.3 \mathrm{~b}$} & $67.06 \mathrm{a}$ \\
\hline Bispyribac-sodium & \multicolumn{2}{|l|}{$29.3 \mathrm{a}$} & $53.93 \mathrm{~b}$ \\
\hline Imazapyr + imazapic & \multicolumn{2}{|l|}{$28.5 \mathrm{ab}$} & $56.39 \mathrm{~b}$ \\
\hline \multirow[t]{3}{*}{ Cyhalofop-butyl } & \multicolumn{2}{|l|}{$30.0 \mathrm{a}$} & $50.89 \mathrm{~b}$ \\
\hline & Total chlorophyll & & Carotenoids \\
\hline & \multicolumn{3}{|c|}{ Concentration in $\left(\mathrm{mg} \mathrm{g}^{-1} \mathrm{FM}\right)$} \\
\hline Control & $1.23 \mathrm{a}$ & & $0.16 \mathrm{a}$ \\
\hline Penoxsulam & $0.99 \mathrm{~b}$ & & $0.11 \mathrm{c}$ \\
\hline Bispyribac-sodium & $1.05 \mathrm{ab}$ & & $0.14 \mathrm{ab}$ \\
\hline Imazapyr + imazapic & $1.10 \mathrm{ab}$ & & $0.14 \mathrm{ab}$ \\
\hline Cyhalofop-butyl & $0.88 \mathrm{~b}$ & & $0.13 \mathrm{bc}$ \\
\hline
\end{tabular}

(1) Lowercase letters compare herbicides in the column by the Duncan's test $(\mathrm{p} \leq 0.05)$.

Other authors have observed that the herbicide penoxsulam causes reduction in chlorophyll $a$ content after application in irrigated rice, demonstrating that even in tolerant plants such as rice these herbicides can generate an oxidative stress condition, changing the chlorophyll $a$ content (Langaro et al., 2016). Chlorophyll a molecules are the main pigments responsible for the capture of light for the photochemical reactions present in the reaction centers of the photosystems. Thus, the decline of these compounds may affect the photosynthetic activity, thus damaging plants growth (Ramesh et al., 2002; Langaro et al., 2016; Marchezan et al., 2017).

The beneficial effect of water depth on weed control is emphasized by several authors, such as Balbinot Jr. et al. (2003) and Machado et al. (2006), who highlight water action eliminating available oxygen to weed roots, thus triggering a series of reactions that culminate in increased weed control. On the other hand, submersion decreases $\mathrm{H}_{2} \mathrm{O}_{2}$ levels in plants that have the ability to adapt to these conditions and may reduce herbicides effects.

The photosynthetic process is a primary process that can be affected by the imposition of stressful situations (Chaves et al., 2009). The electron transfer process between PSII and PSI results in the production of ROS and is part of the normal plant metabolism (Foyer and Noctor, 2000; Müller et al., 2001). In this sense, carotenoids have an important role that is to act as a photo protectors in the prevention of photooxidative damage (Cogdell, 1988; Rau, 1988) and carotenoids are able to prevent reactive action of singlet oxygen produced by chlorophyll (Cogdell, 1988). Photosynthetic systems devoid of carotenoids are not stable in the presence of air and light. Thus, the absence of carotenoids leads to inhibition of chloroplast development through an intricate control system that correlates the expression of chloroplast and nucleus genes (Mayfield and Taylor, 1987).

Results showed less accumulation of $\mathrm{H}_{2} \mathrm{O}_{2}$ in submerged plants (Table 3). Regardless of the soil moisture regime, herbicides in general provided higher levels of TBARS, evidencing cellular damage by these compounds. On the other hand, the antioxidant enzymes activity evaluated was reduced by the herbicide treatments and there was reduction of carotenoids and total chlorophyll.

Considering the results obtained, it can be concluded that $L$. hexandra and L. peruviana growing at field capacity conditions present greater oxidative stress than the plants under submersion. The associations of glyphosate + clomazone and glyphosate + formulation mixture of imazapyr + imazapic results higher oxidative stress in L. hexandra and L. peruviana. E. crus-galli, when in field capacity, presents higher oxidative stress levels than when under submersion conditions. The herbicide penoxsulam provides higher stress in E. crus-galli when these plants are submerged. All herbicides promote lipidic peroxidation in leaves of E. crus-galli, reduction of enzymatic activity and reduction of concentrations of total chlorophyll, chlorophyll $a$ and carotenoids. 


\section{ACKNOWLEDGEMENT}

We thank CNPq (Edital MCT/CNPq N. 014/2010 - UNIVERSAL, N.Proc. 479167/2010-9) and FAPERGS (Edital PRONEM/FAPERGS n. 003/2011, N. Proc. 11/2207-0) for the financing support. CAPES and CNPq are also acknowledged for providing the students scholarships.

\section{REFERENCES}

Abu-Irmaileh B.E., Jordan L.S. Some aspects of glyphosate action in purple nutsedge (Cyperus rotundus). Weed Sci. 1978;26:700-3.

Agostinetto D. et al. Interferência de capim-arroz (Echinochloa spp.) na cultura do arroz irrigado (Oryza sativa) em função da época de irrigação. Planta Daninha. 2007;25:689-96.

Azevedo R.A. et al. Response of antioxidant enzymes to transfer from elevated carbon dioxide to air and ozone fumigation, in the leaves and roots of wild-type and a catalase-deficient mutant of barley. Physiol Plant. 1998;104:280-92.

Balbinot Jr. A.A. et al. Características de plantas de arroz e a habilidade competitiva com plantas daninhas. Planta Daninha. 2003;21:165-74.

Barbosa M.R. et al. Geração e desintoxicação enzimática de espécies reativas de oxigênio em plantas. Ci Rural. 2014;44:453-60.

Barreiros A.L.N.S. et al. Estresse oxidativo: relação entre geração de espécies reativas e defesa do organismo. Quím Nova. 2006;29:113-23.

Blokhina O.B. et al. Antioxidants, oxidative damage and oxygen deprivation stress: a review. Ann Bot. 2003;91:179-94.

Bradford M.M. A rapid and sensitive method for the quantitation of microgram quantities of protein utilizing the principle of protein-dye binding. Anal Biochem. 1976;72:248-54.

Chaves M.M. et al. Photosynthesis and salt stress: Regulation mechanisms from whole plant to cell. Ann Bot. 2009;103:551-60.

Cogdell R. The functions of pigments in chloroplasts. In: Goodwin T.W. editor. Plant pigments. London: Academic Press, 1988. p.183-230.

Cole D.J. Mode of action of glyphosate - a literatura analysis. In: Grossbard E., Atkinson D, editors. The herbicide glyphosate. London: Butterworths, 1985. p.48-74.

Devine M.D. et al. Temperature effects on glyphosate absorption, translocation and distribution in quackgrass (Agropyron repens). Weed Sci. 1983;31:461-4.

Foyer C.H., Noctor G. Oxygen processing in photosynthesis: Regulation and signaling. New Phytol. 2000;146:359-88.

Galon L., Agostinetto D. Comparison of empirical models for predicting yield loss of irrigated rice (Oryza sativa) mixed with Echinochloa spp. Crop Protec. 2009;28:825-30

Galon L. et al. Estimativa das perdas de produtividade de grãos em cultivares de arroz (Oryza sativa) pela interferência do capimarroz (Echinochloa spp.). Planta Daninha. 2007;25:697-707.

Gill S.S., Tuteja N. Reactive oxygen species and antioxidant machinery in abiotic stress tolerance in crop plants. Plant Physiol Biochem. 2010;48:909-30.

Heath R.L., Packer L. Photoperoxidation in isolated chloroplasts. I. Kinetics and Stoichiometry of fatty acid peroxidation. Arch Biochem Biophy. 1968;125:189-98.

Hess F.D. Absorption. In: Herbicide action curse. West Lafayette: Purdue University, 1995. 787 p.

Langaro A.C. et al. Biochemical and physiological changes in rice plants due to the application of herbicides. Planta Daninha. $2016 ; 34: 277-89$

Leite C.R.F. et al. Aspectos fisiológicos, bioquímicos e agronômicos dos herbicidas inibidores da ALS (AHAS). Londrina: Ed. dos Autores, 1998. 
Lichtenthaler H.K. Chlorophyll and carotenoids: pigments of photosynthetic biomembranes. In: Colowick S.P., Kaplan N.O. Methods in enzymology. New York: Academic Press, 1987. p.350-82.

Loreto F., Velikova V. Isoprene produced by leaves protects the photosynthetic apparatus against ozone damage, quenches ozone products, and reduces lipid peroxidation of cellular membranes. Plant Physiol. 2001;127:1781-7.

Machado S.L.O. et al. Consumo de água e perdas de nutrientes e de sedimentos na água de drenagem inicial do arroz irrigado. Ci Rural. 2006;36:65-71.

Mayfield S.P., Taylor W.C. Chloroplasts photoxidation inibits the expression of a set of nuclear genes. Molec Genetics Genomics. 1987;208:309-14.

Marchezan, M.G. et al. Morphological and Biochemical Alterations of Paddy Rice in Response to Stress Caused by Herbicides and Total Plant Submersion. Planta Daninha. 2017;35:1-13.

Menezes V.G., Silva P.R.F. Manejo de arroz-vermelho através do tipo e arranjo de plantas em arroz irrigado. Planta Daninha. 1998;16:45-57.

Moldes C.A. Respostas de enzimas antioxidantes á aplicação do herbicida glyphosate em variedades de soja transgênica e não transgênica [tese] Piracicaba: Escola Superior de Agricultura Luiz de Queiroz, 2006. 92 p.

Müller P., Li X.P., Niyogi K.K. Non-photochemical quenching. A response to excess light energy. Plant Physiol. 2001;125:1558-66.

Noldin J.A. et al. Manejo de plantas daninhas em arroz irrigado. In: Epagri. Arroz irrigado: sistema pré-germinado. Florianópolis: 2002. $173 \mathrm{p}$.

Peixoto P.H.P. et al. Aluminum effects on lipid peroxidation and on activies of enzymes of oxidative metabolism in sorghum. Rev Bras Fisiol Vegetal. 1999;11:137-43.

Pinto J.J.O. et al. Controle de capim-arroz (Echinochloa spp.) em função de métodos de manejo da cultura do arroz irrigado. Planta Daninha. 2008;26:767-77.

Ramesh K. et al. Chlorophyll dynamics in rice (Oryza sativa) before and after flowering based on SPAD (chlorophyll) meter monitoring and its relation with grain yield. J Agron Crop Sci. 2002:188:102-5.

Rau W. Functions of carotenoids other than in photosynthesis. In: Goodwin T.W., editor. Plant pigments. London: Academic Press, 1988. p.231-55.

Sanchotene D.M. et al. Efeito do protetor dietholate na seletividade de clomazone em cultivares de arroz irrigado. Planta Daninha. 2010;28:339-46.

Scherner A. et al. Susceptibility of peruvian watergrass and rice cutgrass to glyphosate under soil moisture variations. Crop Protection. 2017;98:1-7.

Scherner A. et al. Suscetibilidade de duas Gramas-boiadeiras a diferentes formulações de glyphosate. Ci Rural. 2014;44:400-6.

Sergiev I.G et al. The phenyl-urea cytokinin 4PU-30 protects maize plants against glyphosate action. Pestic Biochem Physiol. 2006;85:139-46.

Silva J.F., Silva A.A. Controle de plantas daninhas. Brasília, DF: ABEAS, 1997. 185 p.

Vargas L. Sintomas e diagnose de toxicidade herbicida na cultura da maçã. Bento Gonçalves: Embrapa, 2003. 7p.

Vidal R. Ação dos herbicidas. Porto Alegre: Evangraf, 2002.

Wang S., Narendra S., Fedoroff N. Heterotrimeric G protein signaling in the Arabidopsis unfolded protein response. Proc National Acad Sci. 2007;104:3817-22.

Zabalza A. et al. Oxidative stress is not related to the mode of action of herbicides that inhibit acetolactate synthase. Environ Exp Bot. 2007;59:150-9.

Zimdahl R.L. The effect of competition duration. In: Weed crop competition: a review. Corvallis: Oregon State University, 1980. p.83-93. 